\title{
From Conflict to Consensus? Elite Integration and Democracy in Ghana
}

\author{
Anja Osei \\ University of Konstanz, Department of Politics and Management, \\ P.O. Box 90, 78457 Konstanz, Tel: 07531-88 2389 \\ anja.osei@uni-konstanz.de
}

\begin{abstract}
The paper takes as its starting point Higley and Burton's (2006) contention that no liberal democracy has ever evolved without a 'consensually united elite' which is structurally integrated and shares some general values. The fact that the evolution of a consensually united elite is a very rare event limits the prospects for the worldwide spread of liberal democracy. Ghana, however, could represent one of these rare cases. This paper looks at if and how an elite consensus on the "rules of the game" has emerged in the country and what the potential threats to this consensus are. It pays special attention to the social composition of elites and their patterns of interaction between elites (horizontal integration) as well as the relationship between elites and the wider population (vertical integration).
\end{abstract}

\section{Keywords}

elite theory - Africa - democracy

Election results in Africa are often subject to heated disputes between winners and losers. Well-known examples of violent post-electoral crises include Kenya in 2007 and Côte d'Ivoire in 2001. However, not all politicians in African countries are 'dying to win' (Mueller 2011); Ghana is a case in point. The country's 2012 general elections ended with the narrow victory of John Mahama

* Funding for this research was provided by the Excellence Initiative of the German Research Foundation (DFG). 
and his NDC (National Democratic Congress) party. Although the process was declared free and fair by domestic and international observers, the defeated NPP (New Patriotic Party) claimed electoral fraud and filed a lawsuit to challenge the election result. While the two parties exchanged strong words in the media, the situation remained largely calm. In August 2013 the Ghanaian Supreme Court finally dismissed the claims of voters fraud and declared that President Mahama had been validly elected.

Does the peaceful way in which this dispute was handled indicate that Ghana's elites have learned to play by the rules of the game and settle their conflicts by constitutional means? This paper seeks to address these issues by drawing on theoretical and empirical insights from elite studies, an avenue of research in African politics that has thus far been relatively neglected. The questions to be answered are whether the structure of the Ghanaian elite is conducive to democracy, and what elite research can contribute to the study of regime types in Africa.

The paper takes as its starting point Higley and Burton's (2006: 2ff) contention that no liberal democracy has ever evolved without a 'consensually united elite' that is structurally integrated and shares some general values (ibid.: 1of). The fact that the evolution of a consensually united elite is a very rare event limits the prospects for the worldwide spread of liberal democracy (ibid.: 4). However, Ghana, one of Africa's most democratic countries, could represent one of these rare cases. Despite the fact that Ghana experienced a rapid succession of various military and civilian regimes from its independence until the 1990s, it is today one of Africa's most democratic countries. A number of authors have emphasised the positive role that the domestic elite consensus has played in the transition process (Whitfield 2009; Svanikier 2007; Frempong 2007). This paper seeks to broaden the discussion by devoting attention to the social composition of the elite and the interaction between elites and non-elites.

The paper is structured as follows: Section 1 introduces the debate on the relationship between elite structures and regime types. Section 2 discusses how elite research could contribute to our understanding of regimes in Africa. Section 3 addresses the methodological challenges and the problem of case selection. The second part of the paper is devoted to analysing elite structures in Ghana. Section 4 describes the historical evolution of elite factions since independence and traces the dynamics of conflict and consensus between them. Section 5 portrays Ghana's contemporary political elite and discusses some features of their self-perception and their relationship with non-elites. Finally, Section 6 summarises the findings regarding the extent to which Ghanaian elite structures are conducive to democracy. 
This section introduces important concepts in elite sociology. Two dimensions are central to the relationship between elites and regimes: horizontal integration and vertical integration (Putnam 1976: 107; Hoffmann-Lange 1992: 35; Schmidt 2004). Horizontal integration describes the interrelations between elites and the extent of cooperation between them. Vertical integration is concerned with the relations between elites and the masses (see Kaina 2009).

In a series of papers and books, Higley and Burton (2006; Higley et al. 1991; Higely \& Field 1980) have developed a comprehensive typology of elite structures and corresponding regime types. They distinguish between three ideal types: consensually united, ideologically united, and disunited elites. Consensually united elites are characterised by 'dense and interlocked networks of communication and influence'. This interaction structure 'provides all important elites with access to central decision-making' (Higley et al. 1991: 36). Using social network analysis, empirical evidence for this structure has been found in Western democracies such as Australia, Germany, and the us. In addition to this structural aspect, consensually united elites share basic values and norms of political behaviour and recognise bargaining as an acceptable mode of operation (Higley \& Burton 2006: 11). This consensus on values does not necessarily mean agreement on specific issues, but rather on the rules of the gamein other words, elites must agree to disagree (Engelstad 2010: 70). Consensually united elites are a precondition of democracy (Higley \& Burton 2006: 2).

Ideologically united elites are strongly centralised and united by a distinct ideology (ibid.: 12). Such structures are typical of stable but unrepresentative systems, such as totalitarian systems or theocracies (ibid.).

Disunited elites share neither dense communication networks nor any fundamental agreement on the political norms of behaviour. These weakly integrated elites always form unstable regimes that can be representative to varying degrees (ibid.: 19). ${ }^{1}$

Scholars including Cammack (1990) have voiced important criticism of this theory, arguing that the role of non-elites receives inadequate attention (see also Borchert 2010). There is, of course, a larger debate on the relationship between vertical and horizontal integration. In the view of some researchers, the mere existence of elites contradicts the idea of equality, which is an inherent feature of democracy (Borchert 2010: 24). In recent years, however, elites have increasingly been accepted as an unavoidable feature of modern

1 A detailed discussion of the advantages and disadvantages of this type is beyond the scope of this paper. 
societies (see Engelstad 2010), and the discourse has shifted to more empirical questions: What are the central characteristics of elites in democracies, and how do they differ across various countries? The legitimacy of elites is undeniably a basic requirement in a democracy (Kaina 2009: 400). Ideal-typically, elites should uphold democratic values, act in accordance with the preferences of the electorate, and be demographically representative (Hoffmann-Lange 1986). Reality often falls short of these high expectations, but for empirical research on regime types, it is reasonable to assume that elites in democracies come closer to these ideals than elites in non-democratic systems (for similar argumentation, see Petterson 2010: 124).

Generally speaking, there is always a tension between vertical and horizontal elite integration (Kaina 2009: 409). A horizontally integrated elite structure as described by Higley and Burton fosters mutual understanding between elites and provides them with a 'common language' based on similar experiences in their socialisation (see also Kaina 2009: 408f). This elite autonomy enhances effective political decision-making but may at the same time widen the gap between political representatives and the electorate. Strong vertical integration, on the other hand, makes elites more representative and accountable to their voters, but could hinder political compromises and block decisionmaking (ibid.). For the functioning of democratic systems, both dimensions are indispensable. Consequently, several scholars have suggested including both horizontal and vertical integration in the analysis of elite structures and regime types (Schmidt 2004; Ruostetsaari 2007).

Elite sociology offers interesting theoretical concepts that claim universal applicability. Empirically, however, Africa has remained a blind spot on the research agenda of elite sociology. There has been surprisingly little systematic research on African elites (Daloz 2003: 271). Nevertheless, the idea that elite structures have an impact on the regime type and political stability of a country is implicitly present in the literature on the African state. Elite unity and disunity have primarily been discussed in the context of political clientelism, in which political support is exchanged for material benefits. Many scholars assume that the structure of elite integration can have an enormous impact on the stability of a country. The literature on African elites instead emphasizes political clientelism as a mechanism of elite integration (Lemarchand 1972; Roth 1968). Bayart (1993:152), for example, describes how state resources were used to construct large patronage networks that fused new elites and local Big Men into a national elite group. Clientelism can however not only be a source 
of elite integration, but also of elite conflict. The failure to include important group interests may result in the outbreak of violent conflict (Rothchild \& Foley 1988: 249). Snyder (1992: 384) nicely summarises this point:

$[\ldots][\mathrm{N}]$ eopatrimonial regimes which effectively coop elites through institutionalized patronage networks [...] tend to be relatively stable and long-lived. On the other hand, neopatrimonial regimes which exclude elites from patronage $[\ldots]$ are generally unstable.

Political clientelism has also been discussed in relation to vertical integration. It is often argued that the relationship between rulers and the ruled in neopatrimonial states relies on links between big men and their communities (Chabal and Daloz 2000: 37). If these vertical linkages are broken - for example, because economic crises deprive rulers of the 'ability to maintain political stability through the distribution of material rewards' (Bratton and van de Walle 1994: 460) - this can induce powerful protest from below that may then promote political reform and regime change (Bratton and van de Walle 1992). Naturally, this does not mean that the successor regime will necessarily be less clientelistic. As many authors have noted, material exchange systems have endured in Africa despite the introduction of formal multiparty democracy. However, it does demonstrate that intact linkages between elites and non-elites, whether they rest on common beliefs, ideology, clientelism, or some other mechanism, are a crucial factor for regime survival.

To sum up, this paper argues that the ideas of vertical and horizontal integration are well present in Africanist writing. A theoretically thorough and exhaustive discussion of possible types is beyond the scope of this paper. Instead, it examines the relatively simple research question of whether the elite structure in Ghana resembles what Higley and Burton would describe as a consensually united elite, additionally including the vertical dimension in the analysis. The theoretical expectation is that a democratic country should exhibit a relatively high degree of vertical integration. If evidence of such integration and a consensually united elite is found in Ghana, there would be little reason to believe that the dispute over the election results in 2012 represents a danger to democracy in the country.

\section{$3 \quad$ Case Study Design}

In general, single case studies can be used for theory tests (George and Bennet 2005; Lijphart 1971; Eckstein 1975). However, given that the literature on elites in Africa is relatively underdeveloped, this paper does not seek to implement 
a strong test to prove or disprove a theory. The strategy applied instead corresponds to Eckstein's idea of the plausibility probe, an examination that attempts to determine whether a 'theoretical construct is worth considering at all' (Eckstein 1975: 141) before further tests are made. Thus, the case study will investigate whether the general idea of elite integration is useful for African countries.

As discussed above, Higley and Burton claim that a consensually united elite is a necessary condition for a liberal democracy. Although the authors do not discuss the meaning of liberal democracy in their 2006 book, their usage of the term suggests that it is synonymous with consolidated democracy, a term that they had used in their previous work (Higley and Gunther 1992). Although consolidation is a contested notion, it can be understood as the process by which democracy becomes the only game in town, a development that cannot be easily reversed (Przeworski 1991: 26). In Africa, this describes only a handful of countries. Ghana falls in this category, not only because it scores very high in the Freedom House index, but also because it has passed Huntington's twoturnover test, ${ }^{2}$ which is often seen as a benchmark for successful consolidation.

Furthermore, Ghana is an ideal case in the sense that it is representative of a wider category of African states, namely those that have experienced a rapid alternation between civilian and military regimes. At the same time, Ghana could be a proto-typical case for a smaller set of countries in which elite consensus has been achieved and democratisation has been fairly successful. ${ }^{3}$ In this sense, the single case study focusing on Ghana has a comparative merit (Sartori 1994: 252).

However, it is necessary to be precise about the character of the case study. Three questions will serve as guidelines for the analysis:

1. Which elite factions existed prior to democratisation, and what was the nature of the consensus between them?

2. What is the social composition of the elite today, and what patterns of cooperation or conflict can be observed?

3. What can be said about the vertical integration of elites? (I.e., are they perceived as legitimate? Are they demographically representative?)

To answer these questions, the paper draws on a variety of sources. The description of elite disunity (question one) is a historic narrative that draws

2 According to Huntington (1991), a democracy is consolidated if two peaceful turnovers have occurred after the founding elections.

3 On the logic of representative and prototypical case studies, see Hague et al. 1998: 72. 
on previously published scholarly work. The assessment of the elite consensus and patterns of cooperation (question two) employs secondary sources but also makes use of self-perceptions expressed in qualitative, in-depth interviews with selected MPS and other politicians. Of course, MPs represent only a fraction of the national elite. National legislations are, however, a useful starting point for elite studies because they are among the most crucial institutions in democratising countries (Fish 2006). Moreover, MPs are a well-studied group in many Western societies, but data on Africa is completely missing. In this regard, any information on the social characteristics of Ghanaian legislators has not only a descriptive, but also a possible comparative merit. The interviews took place between September 2012 and August 2013. In order to strengthen the argument, material from expert interviews is used. In addition, biographical data on Members of Parliament from 2008-2012 will shed light on the social composition of the elite. The assessment of the vertical integration of elites (question three) uses the same sources, but adds some insightful data from the Afrobarometer Survey. To compare the social characteristics of MPS with those of the Ghanaian population at large, various documents from the Statistical Service are used.

Elites in Ghana from Independence to the Early 1990's

\subsection{Elite Disunity, Cleavages, and the Military}

This section describes how elite disunity led to the rapid turnover of regimes in Ghana between the 196os and 1990s. The development is best understood as a path dependent process. As Pierson (2000: 63) has argued, a number of outcomes are generally possible under a set of initial conditions. In times of significant change, termed "critical junctures" by Collier and Collier (1991: 27), small and contingent events can have large and enduring consequences that set in motion a path dependent process (see also Pierson 2000: 263). Timing and sequencing of events are of special importance; events that happen at the "wrong" time may have no consequence. If, however, the path has been laid, positive feedbacks lead to increasing returns: "preceding steps in a particular direction induce further movements in the same direction" (Pierson 2000: 252). Because actors face high costs in moving off this path (Bennet and Elmann 2006: 252), particular courses of action can be almost impossible to reverse (Pierson 2000: 251).

The chain of events that finally led to today's elite consensus begins prior to independence. Because the colonial infrastructure was unevenly spread, the important administrative and educational facilities were all located along the 
coast. As a result, a Western-educated, nationalist elite emerged in the predominantly Akan-inhabited southern areas of the Gold Coast. This nationalist elite found its earliest political expression in the UGCC (United Gold Coast Convention), which was founded in 1947. The U GCC claimed liberal values and had a rather elitist political style. In 1949, Kwame Nkrumah defected from the UGCC to found the Convention People's Party (CPP), which appealed strongly to the partially educated, dissatisfied younger elements in society (Apter 1966: 270). This split, although a seemingly small event, laid the basis for two important political groupings, in Ghana commonly referred to as "political traditions" (Jonah 1998). Each of these traditions has a set of core values and is tied to core social groups. The Busia-Danquah tradition, in succession of the UGCC, has always been associated with the wealthy professional and business elites who are mostly belonging to the Akan ethnic group. It claims to stand for the rule of law, liberal democracy, and free-market economic principles. In contrast, the Nkrumahist tradition hails Nkrumah for his opposition to the urban elites and to the chiefs, his anticolonial and anti-imperialist stance, and his sympathy for mass politics (Jonah 1998: 90; Nugent 2007: 260).

Ghana became independent in 1957 under Nkrumah. The major opposition party in the First Republic was the United Party (UP) under the leadership of Busia and Danquah, which tended to represent the same sociological stratum as the UGCC. However, it would be misleading to present Ghanaian politics at that time as a simple class struggle (Pinkney 1972; Rathbone 1973), even though the CPP ideology heavily relied on this narrative. By reserving access to elite positions for party supporters, the CPP created many opportunities for selfenrichment and patronage. It is thus more correct to speak of different elite factions which nevertheless continued to legitimise their claim to power with ideological differences.

In 1966, Nkrumah was overthrown in a military coup, and Lt.-General Joseph Arthur Ankrah, the leader of the National Liberation Council (NLC), became the head of state. Since this was an anti-Nkrumahist coup, it is unsurprising that the NLC relied strongly on social groups and individuals that had not supported the СPP, including the chiefs and former opposition politicians like Busia (Pinkney 1972; Austin 1964; Gyimah-Boadi 1994: 127).In terms of careers and educational patterns the NLC leadership had much in common with the professional elites represented by the Busia-Danquah tradition, and they largely identified with this group (Baynham 1988: 223). The first military coup thus reinforced the already existing pattern of elite conflict. In 1969, the NLC handed over power to the civilian government of Busia's PP (Progress Party), a reincarnation of the UP. The CPP was banned from participating in elections. Busia's government was overthrown by General Acheampong in 1972. 
Because he had cited Nkrumah as his inspiration, many CPP supporters hoped for a revival of Nkrumahism (Hansen \& Collins 1980: 7). At first, Acheampong was able to integrate major interests, but he was soon faced with opposition from the civil society movements, old PP networks, and fractions in the army. Acheampong was removed from power in a palace coup in 1978. The next head of state, Lt.-General Akuffo, announced the return to multiparty politics. In preparation of the election, the Nkrumahists founded the PNP (People's National Party), which embraced the old guard of the CPP and some younger elements (Jeffries 1980:408), and chose the northerner Hilla Limann as its candidate. The Busia-Danquah tradition, unable to present a united front, split into two parties, the PFP (Popular Front Party) and the UNC (United National Convention). Shortly before the elections were held, a military coup under the leadership of Flight Lieutenant Jerry John Rawlings took place. One of the first actions of the new military regime was a so-called 'house cleaning', under which senior officers were imprisoned and some former heads of state were executed, among them Acheampong, and Akuffo (Pieterse 1982: 253). Nevertheless, the elections went on as planned, and Rawlings handed over power to the civilian government of Limann in 1979. Over the following two years, it became clear that the PNP administration would not bring about any substantial progress. The ongoing economic crisis and the alleged continuation of corruption led to the overthrow of Limann in a fresh coup on 31 December 1981. This time, the PNDC (Provisional National Defense Council) - again under the leadership of the charismatic Rawlings - proclaimed a revolution in defence of the common man.

It has been shown so far that political power in Ghana alternated between parties of the Busia-Danquah tradition, the Nkrumahists, and the military. In this regard, the "Rawlings Revolution" was a critical juncture in Ghana's political development with important consequences for the composition of the national elite. In contrast to other military takeovers, this was a revolution of junior officers (Pieterse 1982). The initial support base was dominated by the lower ranks of the army (ibid.: 118), but the promise to end corruption and give power to the people also resounded with many other disenchanted segments of the society (Oquaye 2004: 199). At first, Rawlings tried to establish himself as an alternative to the two older political traditions. However, he shared a strong anti-elite and leftist rhetoric with the Nkrumahists. The PNDC also absorbed some of the old CPP networks and cadres as it built its own power base, thus becoming an 'amalgam of large segments of the CPP and entirely new political groups' (Amponsah 2006: 290). Among these new groups were the cadres of the revolutionary institutions and many young, mostly university-educated technocrats (Nugent 1995: 126f) who would 'not have carried political weight 
if political circumstances had been different' (ibid.: 127). This indicates that a degree of elite renewal took place under the PNDC, even if it was under the guise of an anti-elite revolution.

\subsection{The Transition Period}

The initial revolutionary enthusiasm died down by the end of the 1980s. To manage the economic crisis, the government turned to more pragmatic policies, embarking on a process of structural adjustment. Despite the initial socialist rhetoric of the Rawlings regime, Ghana became an IMF showcase. The cities bore the brunt of the negative impacts of this programme, and urban groups, once key supporters of the PNDC, became increasingly disenchanted with the regime. Rawlings tried to counteract the loss of his former support base by turning to rural groups (Nugent 1995: 138), but this could not halt the political decay. In 1988, the opposition stepped up its activities. The opposition politician Adu Boahen demanded to "break the culture of silence" and called for the restoration of multiparty democracy (Oquaye 2004: 488). Although all political parties were banned under the PNDC, the informal networks of the Busia-Danquah tradition and the Nkrumahists had survived. They now began to form new political groupings: a number of small clubs sprung up in the Nkrumahist camp, and elements from the Busia-Danquah tradition came together in the Busia Danquah Memorial Club. The most important opposition platform, however, the Movement for Freedom and Justice (MFJ), included Nkrumahists as well as Danquahists, and was supported by major civil society associations such as the Ghana Bar Association (GBA), the Trade Unions' Congress (TUC), and the National Union of Ghana Students (NUGS).

The early 1990s were a critical moment for democracy in Africa, and the decisions that were taken in this period of rapid change usually had great consequences. As the wave of pro-democratisation protests swept the continent, incumbent presidents pondered on various options for holding on to power. Their considerations had to take into account at least three factors: the composition and assumed strength of the opposition, the cohesion of the incumbent regime, and the possible reactions of donors and other external actors. In the face of growing reform pressure from donors and domestic groups alike, Rawlings recognised that his regime would not be able to withstand the demands for political liberalisation. He also realised that that he could gain or retain prestige from pledging commitment to democracy in a managed transition. The reform process in the PNDC was nevertheless ambivalent: 'The PNDC was divided on what to do with itself. There were those who wanted to opt out completely from politics. Others wanted to hang onto power arguing that to leave the political scene completely would endanger their safety, especially 
should power fall into the hands of their enemies' (Kedem 2012: 115). In the end, however, leading PNDC figures as well as grass-root supporters seemed to agree to the political liberalisation process initiated by Rawlings.

A constitutional referendum was held in April 1992. The ban on political parties was lifted in May of the same year, and national elections were scheduled for November. This timeline left the opposition only a short time to organise their electoral campaign and thus further enhanced the value of the recognizable labels and organisational networks of the long-standing party traditions (Jeffries 1992: 343). As a result, the 'old' camps formed new parties again. This time, the Busia-Danquah tradition had enough social cohesion to form a single party, the NPP (New Patriotic Party). The Nkrumahists, for their part, were weakened by infighting and formed no less than four different parties. The PNDC transformed itself into a political party, the NDC (National Democratic Congress). In the end, Rawlings was able to win the presidential elections with a clear majority. In reaction, the opposition boycotted the parliamentary elections, and the NPP issued a statement that claimed a 'stolen verdict'. Rawlings' victory had many reasons: his party, the NDC was able to dictate the terms of the transition and enjoyed the advantage of incumbency. Moreover, Rawlings himself enjoyed the image of honesty and was able to attract non-elite and rural audiences (Jeffries 1992: 361 ). He also effectively neutralised the electoral appeal of the other parties: with his commitment to liberal economic policies he had 'stolen the mantle of the Busia-Danquah tradition' (Nugent 1999: 294), and with his frequent reference to Nkrumah he attracted old CPP followers.

The atmosphere following the 1992 elections was heated, and the situation began to pose a serious threat to the stability of the country. Above all, there was a fear that the vacuum arising from the lack of consensus could encourage another group of adventurers to seize power again and completely reverse the whole process' (Frempong 2007: 137). There were, however, important constraints that kept the actors to the chosen path. The NPP had always displayed itself as a pro-democracy force and would have lost credibility with resorting to violent means. The Nkrumahist were simply too weak and preoccupied with in-fighting. The NDC, although rooted in the old military regime and thus the only political force with effective access to repressive apparatus of the state, had the least incentive to leave the path of further democratisation because it had cultivated a strong electoral support base and simply didn't need to resort to repression. In addition, the majority of Ghanaians obviously supported the multiparty system, and any political adventure would thus have borne an incalculable risk. Under the threat of political chaos, a slow process of political reconciliation began. At first, some mediation efforts involving the National House of Chiefs and the Muslim Association were unable to 
achieve any substantial agreement between the government and the opposition (Frempong 2007: 137ff). A breakthrough was finally achieved by the InterParty Advisory Committee (IPAC), 'a loose, non-statutory and voluntary body comprising the EC and all political parties' (Jonah 2005: 6). Although the decisions of the IPAC were non-binding, it helped to create an atmosphere conducive to dialogue (ibid.). Thus, consensus on key areas of the electoral process was achieved prior to the 1996 elections. There was also greater unity on the opposition front. In the Nkrumahist camp, the merger of smaller groups produced the PCP (People's Convention Party), which entered into an alliance with the NPP under its new candidate, Kufuor. The formation of this so-called 'Great Alliance' was seen as a milestone. The shared experience of repression under PNDC rule had brought Danquahists and Nkrumahists closer together, and they began to see themselves as coalition partners rather than enemies (Svanikier 2007: 133). Nevertheless, even this Great Alliance could not break Rawlings' hold on power, although the post-election atmosphere in 1996 was much calmer than four years before. The opposition candidates conceded defeat and congratulated the winner, and Rawlings in turn congratulated the losers for their competitive spirit (Frempong 2007: 147).

After 1996, the Nkrumahists were weakened with every successive election; the primary actors in these contests were now the NPP and the NDC. The NPP always stood firmly in the tradition of its Busia-Danquah lineage, presenting itself as a liberal, pro-business party with a stronghold in the Akan regions. The weakness of the Nkrumahists opened a large political space on the left of the NPP, which was more and more occupied by the NDC. It began to portray itself as a social-democratic party that claims to defend the common man. The year 2000 was another critical juncture. After serving two terms in office, Rawlings declared that he would not stand the presidential elections. His handpicked successor John Evans Atta-Mills then lost against the NPP candidate John Agyekum Kufuor. The transfer of power was remarkably smooth and peaceful, but there was still a lot of mistrust between the political parties. An important step forward was made by the Ghana Political Parties Programme (GPPP), organised by the IEA (Institute of Economic Affairs), an Accra-based NGO committed to the promotion of multiparty democracy. Jean Mensa (2013: 31f), Executive Director of the IEA, recalls the first GPPP-meeting in 2002:

(...) political parties had little experience of meeting together or communicating, let alone working together across party lines. (...) it was in fact the very first time in Ghana's political history that the leaders of all political parties were assembled in one room. It was a bright sunny day, yet inside the IEA conference hall were the meeting took place, the tension 
was palpable. Party officials looked at each other and at the IEA with reservation and deep suspicion. (...) As the meeting meeting progressed, a sense of eagerness emerged in the room, albeit tentative: an eagerness to engage one another in a non-partisan manner, and an eagerness to participate in a programme that would help to establish a constructive milieu and platform for multiparty dialogue.

Until today, leaders of the political parties hold a monthly meeting at the IEA in which they discuss important national issues. These meetings have contributed to an increase in inter-party trust and thus to a more durable elite consenus on the rules of the game. ${ }^{4}$ How important these mediation efforts are became obvious in the 2008 elections, when the political power passed back to the NDC. In the immediate aftermath of these elections, the NPP was somewhat reluctant to accept its defeat but eventually refrained from taking any legal steps. In 2012, the acting president Mills died. Elections were held in December of the same year and were again won by the NDC and its presidential candidate, John Mahama. Just as in 2008, the NPP was a bad loser; this time, escalating the situation, the party filed a lawsuit to challenge the result. However, these confrontations have taken place in the media and in the courts, thus staying within the framework of the constitution.

This historical narrative shows that the evolution of democracy in Ghana was a path-dependent process. The competing elites of the Busia-Danquah and the Nkrumahist tradition struggled for political power for a period of nearly thirty years. All regimes before the Fourth Republic sought more or less rigorously to exclude competing elites from government positions while simultaneously cultivating ties with selected segments of the civil, traditional, and business sectors. Excluded elites were typically banned from politics, forced to go into exile, or even executed. Rawlings' second coup broke the cycle of rapid regime turnovers and served as a source of elite renewal. In the 1990s Rawlings recognised the need to renew his legitimation. He successfully initiated a managed transition. Each step in the process produced a positive feedback: a basic consensus on the rules of the game began to emerge, and elections were becoming fairer and more accepted over time. Mediation efforts by civil society groups and more or less institutionalised platform such as IPAC or GPPP also plaid a crucial role, but their efforts were perhaps so successful because the structure of the political space was relatively clearly structured. Due to the longstanding political traditions the opposition was less splintered than

4 Interview with Ransford Gyampo, Researcher at the Insitute of Economic Affairs (IEA), 24.06.2013, Accra, Ghana. 
in other African countries. The replacement of the Nkrumahists with the NDC produced a two-party system in which the costs of exit - leaving the chosen path of democratic competition and switching to some previously plausible alternative (Pierson 2000: 252) would be enormously high. Elite consensus and institutional reforms have thus been a mutually constitutive process.

In order to shed light on the contemporary dynamics of conflict and consensus, the next section takes a more detailed look at the current state of horizontal and vertical elite integration.

\subsection{Horizontal Integration: The Social Composition of the Parliament}

This section seeks to describe the social composition of the 5 th Ghanaian parliament (2008-2012). The most obvious fact is the underrepresentation of women. There are only 19 women in Ghana's parliament $(8.3 \%)$, whereas women represent $51.2 \%$ of the country's total population. In terms of age, parliamentarians are equally unrepresentative: Their median age is 54.5 years, whereas the median age of the general population in Ghana is only 21.7 years. ${ }^{5}$ Of course, the observation that politicians are predominantly male and older than the rest of the population is by no means unique to Ghana. The representation of religious groups, by contrast, is more equitable: $12.2 \%$ of MPs are Muslim, which is relatively close to the $15.9 \%$ share in the general population.

More revealing are the educational and occupational profiles of the MPs. In comparison to the average Ghanaian, parliamentarians are highly educated (see Figure 2). The overwhelming majority of them hold at least a bachelor's degree, and a substantial number have completed postgraduate studies (master's degree or $\mathrm{PhD}$ ). For Ghana as a whole, in comparison, only $13.6 \%$ of the population have completed secondary or post-secondary education (Ghana Statistical Service 2008: 9).

A large proportion of MPs attended universities and other educational facilities outside Ghana. Of the 84 MPs who studied abroad, 24 went to the UK and eight to the us.

With regard to career patterns, many MPs have a background in the teaching professions (see Figure 3). In addition, there are considerable numbers of lawyers, bankers, businessmen, and other professionals. Nationally, however, managers, professionals, technicians, and other skilled workers together make up only $9.8 \%$ of the population (Ghana Statistical Service 2010: 75). Workers in

$5<$ <ww.indexmundi.com/ghana/median_age.html >, accessed 1.8.2013. 


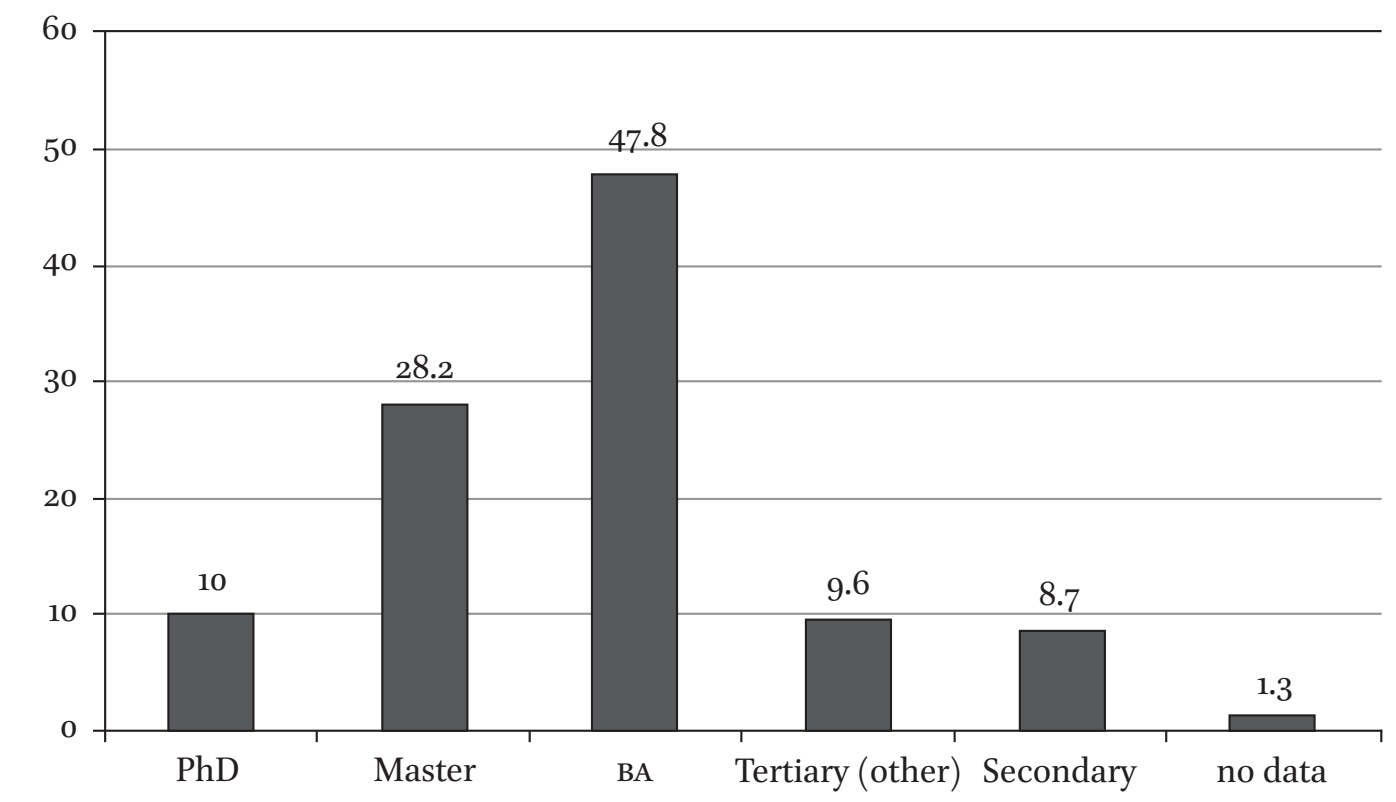

FIGURE 1 Education of MPS.

SOURCE: COMPILED BY THE AUTHOR FROM THE WEBSITE WWW.PARLIAMENT.GH/ MEMBERS/MEMBERS_PARLIAMENT.HTML

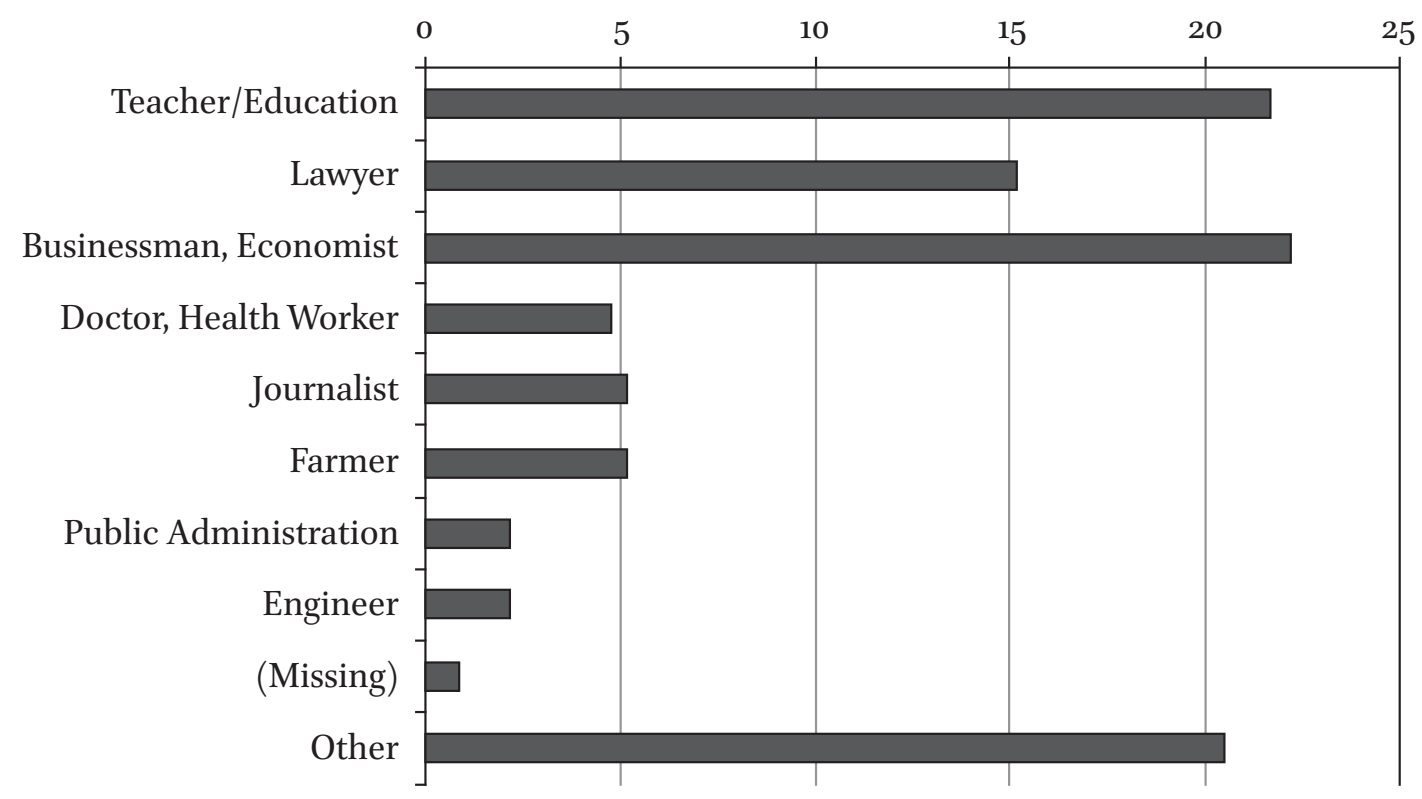

FIGURE 2 Professional Background of MPS.

SOURCE: COMPILED BY THE AUTHOR FROM THE WEBSITE WWW.PARLIAMENT.GH/ MEMBERS/MEMBERS_PARLIAMENT.HTML

the agricultural sector, who at $41.3 \%$ represent the largest group in the general population, are clearly underrepresented in parliament (ibid.).

The tables above clearly show that parliamentarians constitute an elite group that is socially distinct from the average population. Due to a lack of longitudinal data, it is difficult to assess whether the gap between elites and 
non-elites has widened or narrowed in the era of democracy. Although a number of authors have observed that only wealthy individuals can afford election campaigns in contemporary Ghana (Lindberg 2003; Daddieh and Bob-Milliar 2012), there are good reasons to believe that the representativeness of the parliament has increased at least slightly over time. The expansion of secondary and tertiary education (Akyeampong 2010) and the growth of the middle class (African Development Bank 2011) may have increased the pool of those who possess enough financial and social capital to compete for a parliamentary seat. This hypothesis is supported by the fact that the party primaries of the NDC and the NPP are often contested by more than five candidates. The outcome of this process is often influenced by clientelistic and/or influence networks in the party. Nevertheless, the very fact that relatively competitive primaries do take place creates more openness and equitable chances than a purely top-down imposition of candidates. Turnover in the Ghanaian parliament has been high since 1992, and it is not unusual to see even party heavyweights lose their seats. Therefore, it is reasonable to assume that parliamentary democracy is contributing at least modestly to elite renewal and diversification over the long term.

\subsection{Horizontal Integration: Value Consensus and Interaction}

Despite the fact that the parties display a great deal of mutual hostility in the media, MPs from both parties seem to intermingle quite freely in the House of Parliament. As one MP explained, 'We disagree on politics, but we eat together'. ${ }^{6}$ Another MP admitted that the deep antagonism between the NPP and the NDC was a delusion on the part of the voters, because 'in parliament we are one.' ${ }^{7}$ Another factor bringing the parties together is the necessity of collaboration in parliamentary committees. Many of the interviewed MPs indicated that these committees enhance the cooperation between the parties, even if certain decisions are blocked due to the parties' image considerations. In their study, Stapenhurst and Pelizzo (2012: 342) also find a relative absence of partisanship at the committee level. At the same time, MPs expose a high degree of collegiality which results from the experience of working together. The pattern of cooperation in the committees is worth a more detailed account. During the fieldwork, the members of a number of committees were asked to name the people with whom in the committee they discuss important political decisions. ${ }^{8}$ The network structure of these committees, namely

6 Interview with a Member of Parliament, 10.10.2012, Dunkwa, Central Region, Ghana.

7 Interview with a Member of Parliament, 28.9.2012, Accra, Ghana.

8 The question read: "Looking back over the last six months, who are the people in the Committee [name of the committee] with whom you have discussed important political decisions? Please give me their names." Most respondents gave four to five names. 


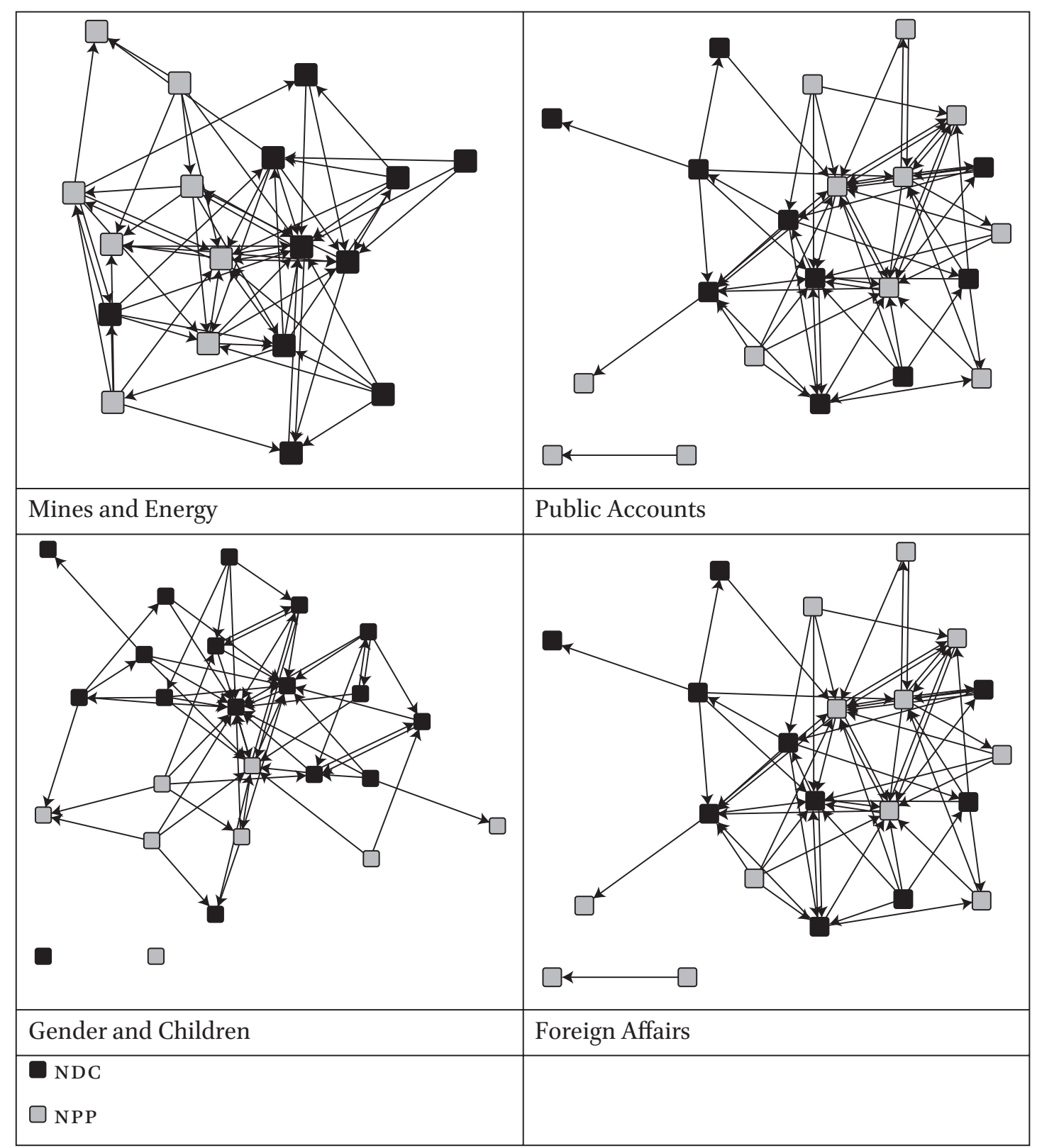

FIGURE 3 Interaction between NDC and NPP MPS in the parliamentary committees.

"Mines and Energy", "Public Accounts", "Gender and Children", and "Foreign Policy", is shown in Figure $3 \cdot{ }^{9}$

It is easy to see that the network are dense, and that there are a number of ties between members of different parties. This can be further illustrated by using two basic concepts of social network analysis: network density and party homophily. Density describes the cohesion or knittedness of a network and is calculated by dividing as the number of ties present in a network by

9 For this paper, all calculations are performed with UCINET. Visone was used for the visualisation of the networks shown in Figures 3. 
the number of theoretically possible ties. The density measure takes on values between $o$ if no ties exist at all, and 1 for a complete network in which every actor is connected to every other. The second concept, homophily, builds on the fact that contacts among similar people - in our case members of the same party - tend to be more frequent than contacts among dissimilar people (McPherson et al. 2001). Homophily can be assessed with the E-I Index which measures the ratio between external $(\mathrm{E})$ and internal (I) ties. The normalized E-I Index takes on values between -1 and +1 , where -1 indicates total homophily, i.e. that all existing ties are formed among members of the same group. An E-I Index of +1 in contrast stands for complete heterophily, meaning that all ties are formed between members of different groups. Table 1 shows an overview of these measures for the four committees of interest.

From this it can be concluded that all networks are rather dense, especially the "Mines and Energy" network. Although relationships among MPs of the same party are slightly more frequent than relationships among MPs of different parties, the levels of homophily are still relatively low, and even close to zero in the Mines and Energy and Gender committee. The committees can thus be seen as one of the important arenas of elite integration.

In addition, the politicians interviewed in Accra in 2012 all stated that democracy was preferable to any other form of government. A study by the Center of Democratic Development (CDD) indicates that Ghana's elites see elections as the only path to power. These results raise the question of to what extent genuine support for democracy is being expressed and to what extent the answers are influenced by interview effects. More significantly, all interviewed politicians held more or less the same view regarding their duties as MPs. They see themselves first as lawmakers, but also as 'agents of community development. ${ }^{10}$ Irrespective of their party affiliation, MPs complained

TABLE $1 \quad$ Network density and E-I Index of selected committees

\begin{tabular}{lll}
\hline Committee & Density & E-I Index \\
\hline Mines and Energy & 0,22 & $-0,20$ \\
Public Accounts & 0,14 & 0,06 \\
Foreign Affairs & 0,15 & $-0,26$ \\
Gender and Children & 0,11 & $-0,09$ \\
\end{tabular}


that their constituents expected them to provide virtually everything for the community - from public goods such as roads and hospitals to private goods such as school fees and jobs. An NDC MP from the Upper West Region has expressed this in the following words:

I come from a constituency that is bedevilled with its bad roads. I have found myself in the ministry that my constituents will be looking forward to have their roads fixed. In the area of education, my constituents also think I should be able to support a list of the young boys and girls to get into training institutions, health institutions, colleges. ${ }^{11}$

An NPP MP from the Central Region faces very similar challenges:

My constituents expect me to promote their welfare and their economic advancement, to promote the development of the area, to keep close contact with them, and to provide effective leadership for the community. ${ }^{12}$

Politicians from both parties must respond to similar demands from their communities, and failure to adequately respond often represents a major threat to re-election. This observation is in line with earlier work on clientelism and elections in Ghana (see Lindberg 2003; Nugent 2005). The wider implication for elite studies is that MPs share the same living conditions and social experiences; they also often have a similar educational and career background. These factors provide a psychological basis that facilitates intermingling (Putnam 1976: 108) and reinforces horizontal integration.

\subsection{Vertical Integration: Elites and Non-Elites}

However, we must not overlook the fact that the NDC has always been more open to people from the lower social classes. In 1992, the one-sided parliament mostly consisted of people with 'working class backgrounds, e.g. pupil teachers, clerks and farmers' (Daddieh and Bob-Miliar 2012: 211). Later, the party tried to file more high-profile candidates, but even now there are striking differences between the parties in this regard (see Figure 4).

Given the social composition of the Busia Danquah tradition, it should come as no surprise that the majority of NPP MPs come from the law professions. This professional and social difference between the parties can also be seen in the fact that almost half of the NPP representatives have been educated

\footnotetext{
11 Interview with a Member of Parliament, 11.07.2013, Accra, Ghana.

12 Interview with a Member of Parliament, 26.06.2013, Accra, Ghana.
} 


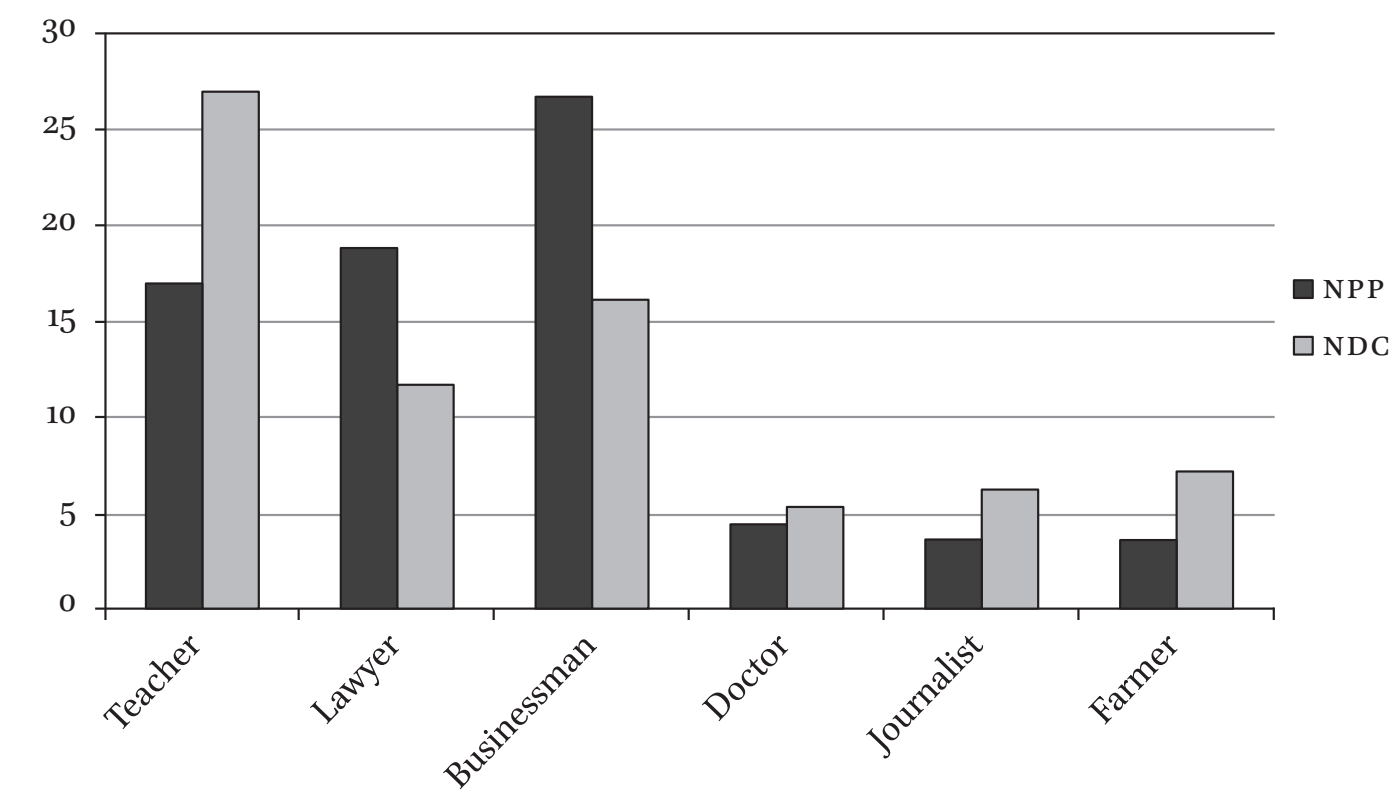

FIGURE 4 Profession of NDC and NPP MPS.

SOURCE: COMPILED BY THE AUTHOR FROM THE WEBSITE WWW.PARLIAMENT.GH/ MEMBERS/MEMBERS_PARLIAMENT.HTML

TABLE 2 Education of NDC and NPP MPS

\begin{tabular}{ll}
\hline Party & Studied abroad (in \%) \\
\hline NPP & 49.1 \\
NDC & 29.7 \\
\hline
\end{tabular}

Source: Compiled by the author from the website www.parliament.gh/members/members_ parliament.html

outside of Ghana, while this is true for only slightly more than a quarter of NDC MPs (see Table 1).

This data clearly confirms Nugent's assumption that 'most of the NDC leadership comes from more humble social origins - lower ranks of the army or teaching professions - and has a modest educational profile' (Nugent 2007:262). It also fits the NDP's self-description as a social-democratic party. ${ }^{13}$

For a more effective assessment of vertical integration, data sets from surveys of elites and the general population using similar questions would be

13 See the 2008 Manifesto 'Better Ghana' and the 2012 Manifesto 'Advancing better Ghana', which can be found at the official website: $<$ http://ndc.org.gh/\#>, accessed 1.8.2013. 
necessary. Although we do not have access to such data, the Afrobarometer Survey can provide some insights into public opinion in the country. ${ }^{14}$ In Round 5 , which took place in $2012,82 \%$ of respondents expressed the opinion that democracy is 'preferable to any other kind of government', and $74 \%$ were fairly or very satisfied with the way democracy worked in the country. Voter turnout in 2012 was $80.15 \%$ (EC Ghana). At first glance, these findings are impressive. However, a more detailed examination of the data reveals that some indicators of vertical integration are declining. Figure 5 displays how four interesting measures have developed over time:

- the number of people who trust the parliament to a moderate or great degree,

- the number of people who believe that their MP listens to their concerns often or always, and

- the perception of corruption among MPs.

As the figure clearly indicates, trust in the parliament peaked in Round 4, but is now in decline. The perception that MPs listen to their constituents, always

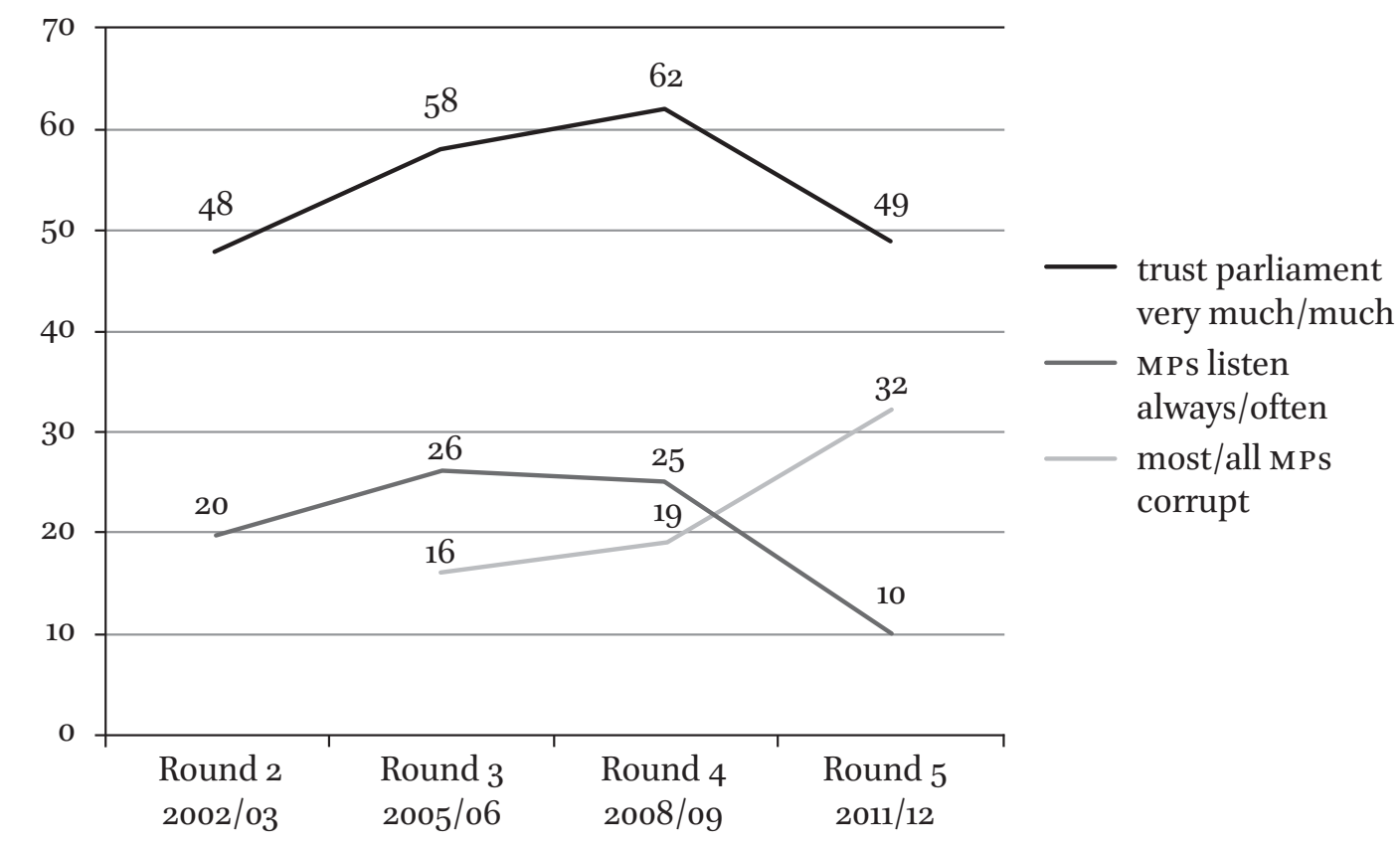

FIGURE 5 Vertical elite integration in Ghana.

SOURCE: AUTHOR'S COMPILATION

14 The Afrobarometer measures the social, political, and economic atmosphere in Africa. See $<$ www.afrobarometer.org $>$, accessed 1.8.2013. 


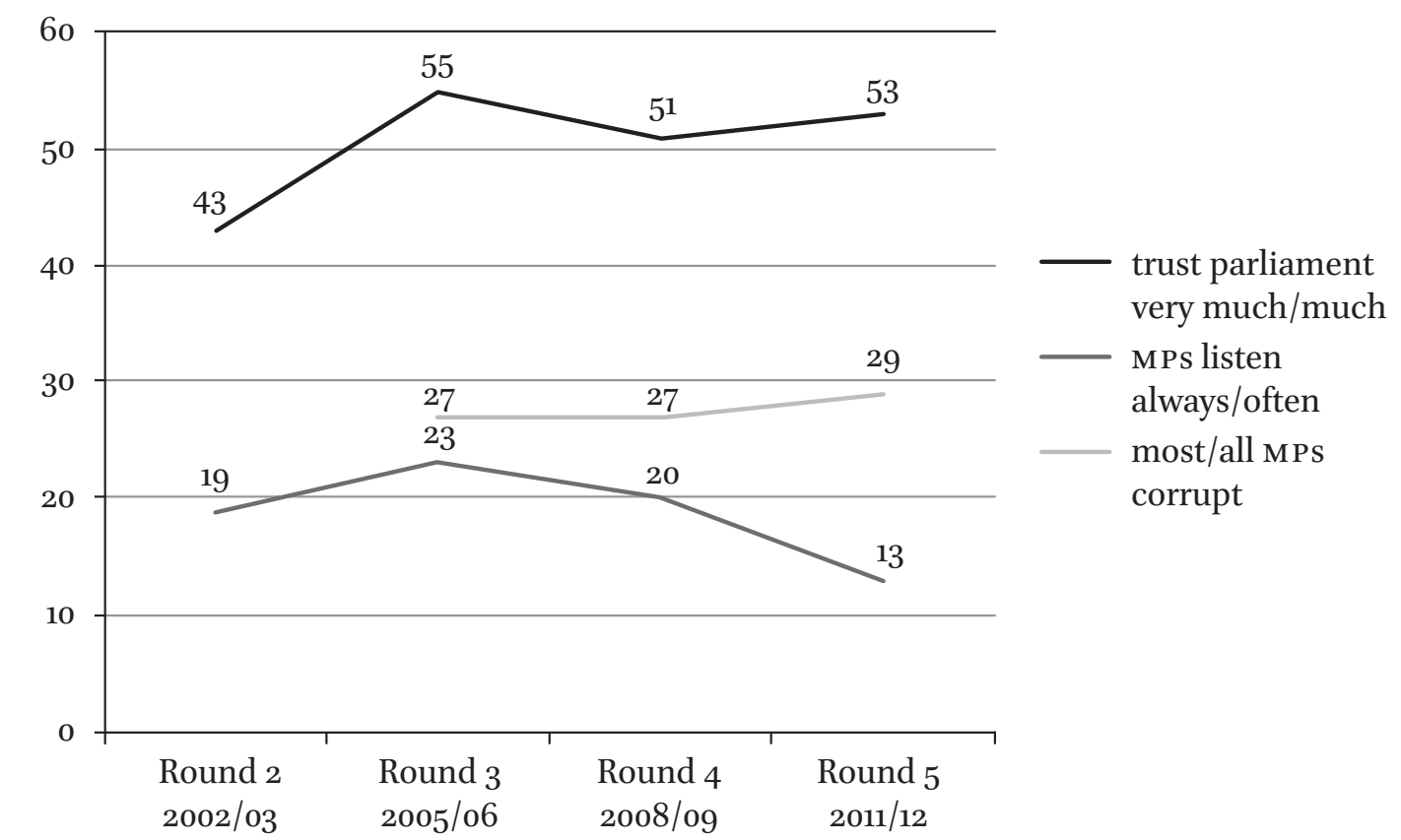

FIGURE 6 Vertical elite integration (all afrobarometer countries). SOURCE: AUTHOR'S COMPILATION

rather low, has dropped to an all-time low in Round 5. By contrast, an increasing number of people regard most or all MPs as corrupt. A comparison with the Afrobarometer average ${ }^{15}$ shows that Ghanaians have less trust in their parliament, and that they are more inclined to believe in the corruption of their MPs. Ghanaians are also less convinced that their representatives listen to them than the Afrobarometer respondents in other countries.

Given the generally high level of support for democracy among Ghanaians, these figures are not yet alarming. However, they can be interpreted as representing a downward trend in vertical integration. As elites become more integrated at the horizontal level, they may lose touch with their voters. As discussed in the theoretical section 2, this is the typical tension between horizontal and vertical integration.

\section{Conclusion}

As the rapid succession of administrations suggests, Ghanaian elites were profoundly divided for most of the country's post-independence history. The fault line ran between the Busia-Danquah tradition, deeply rooted in the Akan regions and among business and traditional elites, and the Nkrumahists, with

15 The survey currently includes 35 Sub-saharan countries. 
their more leftist orientation. All regimes before the Fourth Republic sought more or less rigorously to exclude competing elites from government positions while simultaneously cultivating ties with selected segments of the civil, traditional, and business sectors. Excluded elites were often banned from politics, forced to go into exile, or even executed. The military regimes themselves were influenced by the polarised nature of politics although the provided a source of limited elite renewal. This was especially true of the Rawlings revolution. The Rawlings regime had a second important effect as well: The experience of oppression led old enemies from the Busia-Danquah tradition and the Nkrumahists to work together. With the sidelining of the Nkrumahists in later years, the characteristic polarisation of Ghanaian politics resurfaced on a new level, this time between the centre-right NPP and the populist, social-democratic NDC. The agreement between these two parties on the rules of the game is a decisive achievement. Although the PNDC took the first steps in the transition process in order to preempt social unrest, the pressure from civil society movements and international donors certainly helped to push the parties towards consensus. Each step in the process produced a positive feedback, and elections and elite consensus became a mutually constitutive process.

The current state of affairs represents a positive and mutually beneficial relationship between vertical and horizontal integration. Both parties have been able to mobilise a substantial number of voters, thus creating two strong political poles of almost equal strength. In the emergent two-party system, the costs associated with breaking up the elite consensus would be enormously high. Neither of the parties would actually gain anything, but would instead face opposition from a large segment of Ghanaian society. Moreover, Members of Parliament from both of the major parties share the same social space, interacting and intermingling frequently. This interaction provides the common language and group consciousness that are typical of highly integrated elites. Given these findings, Ghana's elites seem to fit well into the 'consensually united' category of the Higley and Burton framework. Of course, this does not mean that there are no political conflicts in Ghana. With the onset of oil production in the country, the stakes in the political race have become higher, and each party is eager to win the next election. In this regard, the lawsuit alleging irregularities in the 2012 election was indeed a test case for the country. The fact that the opposition finally accepted the ruling of the court without any violent protest demonstrates that a consensus on the rules of the game has indeed been achieved.

There is nevertheless an inherent danger arising from the tension between horizontal and vertical integration. The problem is twofold: Politicians from 
all parties 'eat together' in the parliament, but nevertheless they mobilise their voters by displaying very strong party identities. It is thus unclear whether the consensus on democratic procedures at the elite level is equally well communicated to the grassroots level of the parties. Disenchanted NPP and NDC footsoldiers may try to push their party elites to take more partisan positions - i.e., to emphasise vertical integration - which could come at the expense of horizontal integration. In the long term, there is another potential danger. As we have seen, elites in Ghana have found commonalities and formed closer relationships, but at the same time they may be losing touch with their constituents. This raises the prospect of disillusionment among the wider population, a danger that can take many forms: apathy, anti-elite riots, or the rise of new political forces along old or new themes.

\section{References}

African Development Bank (AfDB). 2011. The Middle of the Pyramid: Dynamics of the Middle Class in Africa. AfDB Market Brief, April 2o. Tunis: African Development Bank (AfDB).

Akyeampong, Kwame. 2010. "Educational Expansion in Ghana: A Review of 50 Years of Challenge and Progress". University of Sussex, Centre for International Education, Sussex: Consortium for Research on Educational Access, Transitions and Equity, Research Monograph No. 33 .

Amponsah, Nicholas. 2006. "Political Traditions and Electoral Politics in Kintampo North and South, Sissala West and Wa Central." Pp. 287-307 in Voting for Democracy in Ghana: the 2004 elections in perspective. Vols. 1 \& 2., edited by K. Boafo-Arthur. Accra: Freedom Publications.

Apter, David. 1966. "Ghana." Pp. 259-313 in Political Parties and National Integration in Tropical Africa, edited by J. Coleman and C.G. Rosberg. Berkeley: University of California Press.

Austin, Dennis. 1964. Politics in Ghana: 1946-1960. London: Oxford University Press.

Bayart, Jean-Francois. 1993. The State in Africa: The Politics of the Belly. London: Polity.

Baynham, Simon. 1988. The Military and Politics in Nkrumah"s Ghana. Boulder, Co: Westview Press.

Bennett, Andrew and Colin Elman. 2006. "Complex Causal Relations and Case Study Methods: The Example of Path Dependence”. Political Analysis 14(3): 250-67.

Borchert, Jens. 2010. “'They Ain't Making Elites Like They Used To': The Never Ending Trouble With Democratic Elitism." Pp. 25-42 in Democratic Elitism: New Theoretical and Comparative Perspectives, edited by H. Best and J. Higley. Leiden, Boston: BRILL, 25-42. 
Borgatti, Stephen P. et al. 2002. Ucinet for Windows: Software for Social Network Analysis. Harvard, MA: Analytic Technologies.

Brandes, Ulrik and Dorothea Wagner. 2004. "visone - Analysis and Visualization of Social Networks." Pp. 321-340 in Graph Drawing Software, edited by M. Jünger and P. Mutzel. Heidelberg, Berlin: Springer.

Bratton, Michael and Nicholas van de Walle. 1994. "Neopatrimonial Regimes and Political Transitions in Africa." World Politics 46, 4: 453-89.

- 1992. "Popular Protest and Political Reform in Africa." Comparative Politics 24, 4: 419-42.

Cammack, Peter. 1990. "A Critical Assessment of the New Elite Paradigm." American Sociological Review 55, 3: 415-420.

Chabal, Patrick and Jean-Pascal Daloz. 2000. Africa Works: Disorder as Political Instrument. Oxford:James Currey.

Collier, Ruth Berins and David Collier. 2002. Shaping the Political Arena: Critical Junctures, the Labor Movement, and Regime Dynamics in Latin America. University of Notre Dame Press.

Daddieh, Cyril K. and George M. Bob-Milliar. 2012. "In Search of 'Honorable' Membership: Parliamentary Primaries and Candidate Selection in Ghana." Journal of Asian and African Studies 47, 2: 204-220.

Daloz, Jean-Pascal. 2003. "'Big Men' in Sub-Saharan Africa: How Elites Accumulate Positions and Resources." Pp. 271-286 in Elite Configurations at the Apex of Power, edited by M. Dogan. Leiden, Boston: BRILL.

Eckstein, Harry. 1975. "Case Studies and Theory in Political Science." Pp. 79-138 in Handbook of Political Science, Vol 7, edited by F.I. Greenstein. Reading, MA: Addison-Wesley.

Engelstad, Frederik. 2010. "Democratic Elitism: Conflict and Consensus." Pp. in Democratic Elitism: New Theoretical and Comparative Perspectives, edited by H. Best and J. Higley. Leiden, Boston: BRILL.

Erdmann, Gero and Ulf Engel. 2007. "Neopatrimonialism Reconsidered: Critical Review and Elaboration of an Elusive Concept." Commonwealth and Comparative Politics 45, 1: 95-119.

Field, George Lowell and John Higley. 1980. Elitism. London: Routledge \& Kegan Paul.

Fish, M. Steven. 2006. "Stronger Legislatures, Stronger Democracies". Journal of Democracy $17(1): 5^{-20 .}$

Frempong, Alexander K.D. 2007. "Political Conflict and Elite Consensus in the Liberal State." Pp. 128-164 in Ghana: One Decade of the Liberal State, edited by K. BoafoArthur. London: CODESRIA/Zed Books.

Gazibo, Mamadou. 2012. "Can Neopatrimonialism Dissolve into Democracy?" Pp. 79-89 in Neopatrimonialism in Africa and Beyond, edited by D.C. Bach and M. Gazibo. London and New York: Routledge. 
George, Alexander L. and Andrew Bennett. 2005. Case Studies and Theory Development in the Social Sciences. Cambridge and London: MIT Press.

Gyimah-Boadi, Emmanuel. 1994. "Associational Life, Civil Society, and Democratization in Ghana." Pp. 125-148 in Civil Society and the State in Africa, edited by J.W.D. Harbeson, D. Rothchild, and N. Chazan. Boulder, co: Rienner.

Hague, Rod and Martin Harrop. 1998. Comparative Government and Politics: An Introduction. Houndsmill: Palgrave Macmillan.

Hansen, Emmanuel and Paul Collins. 1980. "The Army, the State, and the 'Rawlings Revolution' in Ghana." African Affairs 79, 314: 3-23.

Higley, John et al. 1991. "Elite Integration in Stable Democracies: A Reconsideration." European Sociological Review 7, 1: 35-53.

Higley, John and Richard R. Gunther. 1992. Elites and Democratic Consolidation in Latin America and Southern Europe. Cambridge: Cambridge University Press.

Higley, John and Michael G. Burton. 2006. Elite Foundations of Liberal Democracy. Lanham: Rowman \& Littlefield.

_.1989. "The Elite Variable in Democratic Transitions and Breakdowns." American Sociological Review 54, 1: 17-32.

Hoffmann-Lange, Ursula. 1992. Eliten, Macht und Konflikt in der Bundesrepublik. Opladen: Leske + Budrich.

— 1986. "Eliten und Demokratie in der Bundesrepublik." Pp. 318-338 in Politische Wissenschaft und politische Ordnung: Analysen zu Theorie und Empirie demokratischer Regierungsweise, edited by M. Kaase. Opladen: Westdeutscher Verlag.

Huntington, Samuel. 1991. The Third Wave: Democratization in the Late Twentieth Century. Norman: Oklahoma University Press.

Jeffries, Richard. 1980. "The Ghanaian Elections of 1979." African Affairs 79, 316: 397-414. Jonah, Kwesi. 2005. Inter-Party Dialogue in Ghana. Accra: Institute of Economic Affairs (IEA).

- 1998. "Political Parties and the Transition to Multi-Party Politics in Ghana." Pp. 83-107 in Ghana: Transition to Democracy, edited by K.A. Ninsin. Dakar: CODESRIA.

Kaina, Viktoria. 2009. "Eliteforschung." Pp. 358-419 in Politische Soziologie. Ein Studienbuch, edited by V. Kaina and A. Römmele. Wiesbaden: vs Verlag für Sozialwissenschaften.

Kedem, Kosi. 2012. In Pursuit of My Destiny: Memoirs of a Parliamentarian. Governance and Electoral Systems Agency: Accra.

Lemarchand, René. 1972. "Political Clientelism and Ethnicity in Tropical Africa: Competing Solidarities in Nation-Building." American Political Science Review 66, 1: 68-90.

Lijphart, Arendt. 1971. "Comparative Politics and the Comparative Method." American Political Science Review 65, 3: 682-693. 
Lindberg, Staffan I. 2003. “'It's our Time to “Chop"': Do Elections in Africa Feed NeoPatrimonialism rather than Counter-Act it?" Democratization 10, 2: 121-140.

McPherson, Miller, Lynn Smith Lovin and James M. Cook. 2001. "Birds of a Feather: Homophily in Social Networks". Annual Review of Sociology 27(1):415-44.

Mensa, Jean. 2013. "Ghana: Facilitating Multiparty Dialogue: The Importance of a Neutral Broker" Pp. 29-44 in The Power of Inter-Party Dialogue. Our Stories, edited by Roel von Meijenfeldt et al. The Hague: Netherlands Institute for Multiparty Democracy (NIMD).

Mueller, Susanne D. 2011. "Dying to Win: Elections, Political Violence, and Institutional Decay in Kenya." Journal of Contemporary African Studies 29, 1: 99-117.

Nugent, Paul. 2007. "Banknotes and Symbolic Capital." Pp. 252-275 in Votes, Money, and Violence, edited by M. Basedau et al. Uppsala: Nordiska Afrikainstitutet.

- 1999. "Living in the Past: Urban, Rural and Ethnic Themes in the 1992 and 1996 Elections in Ghana." Journal of Modern African Studies, 37, 2: 287-319.

- 1995. Big Men, Small Boys, and Politics in Ghana:Power, Ideology, and the Burden of History, 1982-1994. London and New York: Frances Pinter.

Oquaye, Mike. 2004. Politics in Ghana, 1982-1992: Rawlings, Revolution, and Populist Democracy. Accra Ghana: Tornado Publications.

Petterson, Thorleif. 2010. "Pro-democratic Orientations, Political Shortcuts and Policy Issues: Comparative Analyses of Elite-Mass Congruence in Old and New Democracies." Pp. 117-146 in Democracy Under Scrutiny: Elites, Citizens, Cultures, edited by U. Van Beek. Opladen: Budrich.

Pierson, Paul. 2000. "Increasing Returns, Path Dependence, and the Study of Politics". The American Political Science Review 94(2): 251-67.

Pieterse, Jan. 1982. "Rawlings and the 1979 Revolt in Ghana." Race \& Class 23, 4: 251-273. Pinkney, Robert. 1972. Ghana under Military Rule 1966-1969. London: Methuen.

Przeworski, Adam. 1991. Democracy and the Market: Political and Economic Reforms in Eastern Europe and Latin America. Cambridge: Cambridge University Press.

Putnam, Robert D. 1976. The Comparative Study of Political Elites. Englewood Cliffs, N.J.: Prentice-Hall.

Rathbone, Richard. 1973. "Businessmen in Politics: Party Struggle in Ghana, 1949-1957." Journal of Development Studies 9, 3: 390-401.

Reno, William. 1998. Warlord politics and African states. Boulder, co: Lynne Rienner Publishers.

Roth, Gunther. 1968. "Personal Rulership, Patrimonialism, and Empire-Building in the New States." World Politics 20, 2: 194-206.

Rothchild, Donald and Michael W. Foley. 1988. "African States and the Politics of Inclusive Coalitions." Pp. 149-171 in The Precarious Balance: State and Society in Africa, edited by D. Rothchild and N. Chazan. Boulder, co: Westview Press. 
Ruostetsaari, Ilkka. 2007. "Nordic Elites in Comparative Perspective." Comparative Sociology 6, 1-2: 158-189.

Schmidt, C. 2004. "Theoretische und praktische Aspekte der Eliteforschung." Hitotsubashi Journal of Social Studies 36, 1: 29-43.

Stapenhurst, Rick, und Riccardco Pelizzo. 2012. "Research Note: Improving Democracy and Accountability in Ghana: The Importance of Parliamentary Oversight Tools". Governance: An International Journal of Policay, Adminsitration, Institutions 25(2): $335-46$.

Svanikier, Johanna O. 2007. "Political Elite Circulation: Implications for Leadership Diversity and Democratic Regime Stability in Ghana." Comparative Sociology 6, 1-2: 114-135.

Whitfield, Lindsey. 2009. “'Change for a Better Ghana': Party Competition, Institutionalization and Alternation in Ghana's 2008 Elections." African Affairs 108, 433: 621-641. 